\title{
Plants Biodiversity in Olive Orchards and Surrounding Landscapes from a Conservation Biological Control Approach ${ }^{\dagger}$
}

\author{
María Villa ${ }^{1}$, Sónia Santos ${ }^{2}$, Carlos Aguiar ${ }^{1}$ and José Alberto Pereira ${ }^{1, *}$ \\ 1 Centro de Investigação de Montanha (CIMO), ESA, Instituto Politécnico de Bragança; Campus de Santa \\ Apolónia, 5300-253 Bragança, Portugal; mariavillaserrano@gmail.com (M.V.); cfaguiar@ipb.pt (C.A.); \\ jpereira@ipb.pt (J.A.P.) \\ 2 CIQuiBio, Barreiro School of Technology, Polytechnic Institute of Setúbal, Rua Américo da Silva Marinho, \\ 2839-001 Lavradio, Portugal \\ 3 Linking Landscape, Environment, Agriculture and Food (LEAF), Instituto Superior de Agronomia, \\ Universidade de Lisboa, Tapada da Ajuda, 1349-017 Lisboa, Portugal; sonia.santos@estbarreiro.ips.pt \\ * Correspondence: jpereira@ipb.pt; Tel.: +351-273-330-818 \\ + Presented at the 1st International Electronic Conference on Plant Science, 1-15 December 2020; Available \\ online: https://iecps2020.sciforum.net/.
}

Published: 30 November 2020

\begin{abstract}
Many natural control agents of olive pests need pollen and nectar from non-crop plants in order to complete their life cycles. However, a deep knowledge about the occurring plant species in the agroecosystem is necessary to select the plant species to be maintained or enhanced from a conservation biological control approach. Thus, in this study the goal was to increase the understanding about the plants biodiversity in an important olive producing region in the northeast of Portugal. For that, in a weekly basis during spring and every other week in summer and autumn blooming plant inventories were accomplished in three olive orchards with spontaneous vegetation and its surroundings (woody and herbaceous vegetation areas) from April to December of 2012 and 2013. The percentage ground cover for each flowering plant species was recorded following the Daubenmire cover scale modified by Bailey. A total of 258 plant species belonging to 47 families were identified. The most abundant family was Asteraceae followed by Poaceae, Fabaceae and Brassicaceae Several species were specific of each land use and presented different flowering periods, representing a potential variety of food sources across the seasons. Additionally, some of the identified species are known for their implications as providers of key requisites for natural control agents. These result provided with valuable information for the implementation of conservation biological control measures.
\end{abstract}

Keywords: food sources; pollen; nectar; natural enemies; pest control; mediterranean areas

\section{Introduction}

Conservation of beneficial arthropods can involve an important economic value through the provision of multiple ecosystem services (e.g., pollination, pest control, decomposition) [1,2]. This involves a deep knowledge of the occurring natural resources required by natural enemies and pests as well as the occurring resources in the agricultural landscape. Flowering plants are in many cases among the most important natural resources for arthropods because many of them relays on flowering resources for survival and reproduction in some stages of the life cycle (e.g., [3]).

The olive orchard agroecosystem is one of the main crops in Mediterranean areas around the word. In the northeast of Portugal, one of the most important olive producer regions in the country, the crop is attacked by several pests, such as the olive fly Bactrocera oleae (Rossi) (Diptera: Tephritidae) 
or the olive moth Prays oleae (Bern.) (Lepidoptera: Praydidae). These pests coexist with multiple beneficial arthropods such as the predator Chrysoperla carnea s.l. (Neuroptera: Chrysopidae), several species of syrphids (Diptera) (predators and pollinators) or parasitoids. These arthropods may benefit from flower resources occurring in the agricultural landscape [4-10]. Vegetation within and/or around the olive orchard have been associated to an increase of natural enemies [7,11-13], specific plants were associated to the increase of predator abundance in olive ground covers [13] and in some cases a pest reduction was associated to an increase of natural enemies $[7,14]$.

Additionally, a variation in the plant communities in different olive producer regions is expected according to multiple factors such as environmental conditions or management practices at the landscape or at the local scale. In this context, the knowledge of the plant community in different agricultural areas is necessary for determining which plant resources should be maintain, enhance or studied for conservation biological control. Thus, the goal of this work was to describe the flowering plant community in spring, summer and autumn in the ground cover of olive orchards and adjacent herbaceous and scrubland seminatural areas from the northeast of Portugal in order to analyze it potential for enhancing conservation biological control in olive orchards.

\section{Experiments}

\subsection{Study areas}

The study areas were three olive orchards of approximately 2 ha in area (Cedães: $41^{\circ} 29^{\prime} 16^{\prime \prime} \mathrm{N}-$

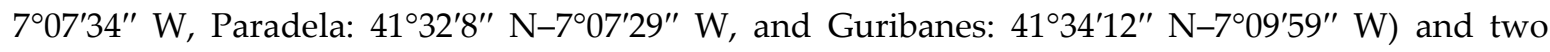
surrounding non-crop areas next to each olive grove, one herbaceous vegetation plot and one scrubland, both of approximately $1 \mathrm{ha}$. During the experimental years, the olive groves were not tilled and were not sprayed with pesticides.

\subsection{Flowering Plant Inventories}

Five flowering plant inventories were carried out every week from April through June and every other week from July through December 2012 and 2013. Inventories were carried out in circular plots of $25 \mathrm{~m}^{2}$ (olive groves and herbaceous patches) and three plots of $100 \mathrm{~m}^{2}$ (scrubland patches). The plots were larger in the scrublands because the larger size of the plant species (trees and shrubs) required inventories to be conducted in larger plots to record the occurring plants. This resulted in a total of 39 samples of plant inventories per sampling date for characterizing the plant community of the olive grove agroecosystem. The percentage ground cover for each flowering plant species was recorded following the Daubenmire cover scale modified by Bailey [15].

\subsection{Data Analysis}

\subsubsection{Alpha Diversity}

The richness, the Pielou's evenness index, the Shannon-Wiener diversity index and the Simpson diversity index were calculated to describe the plant communities in spring, summer and autumn in the olive orchards, herbaceous and scrubland plots using the "vegan" package [16] in R software [17].

\subsubsection{Beta Diversity}

Venn graphics were drawn to visualize the number of shared and unshared species among land uses by season. Plant communities by land use and location were visualized using nonmetric multidimensional scaling (NMDS) (999 permutations) plots (bray distance and $\mathrm{k}=2$ ) after grouping data by the mean of the percentage observed in the samples each date (metaMDS function from "vegan" package).

A Permutational Multivariate Analysis of Variance (PERMANOVA) for each season was used to analyze the differences among plants communities from the different land uses (olive orchards, herbaceous and scrubland patches) and locations (Cedães, Paradela, Guribanes) using the function 
adonis2 from the same package. Square root of the abundance matrix was used for minimizing the influence of most abundant groups. Then, the Bray-Curtis dissimilarity matrix was used as response and land use and location as explanatory variables. The main effects and the interaction were analyzed. Permutations were constrained by sample. 999 permutations were used. In order to analyze which levels of the significant explanatory variables and/or interactions were significantly different a pairwise comparison for each group level with Bonferroni correction for multiple testing was performed using pairwise permutational MANOVA with the function pairwise.perm.manova from the "RVAideMemoire" package (Hervé, 2020). Following the 'marginality principle' when non-nullinteractions stood out, main effects were not analyzed (Nelder, 1977). The plant species driving the differences were analyzed with a similarity percentage analysis (SIMPER) of the square rooted abundance matrix using the simper function in the "vegan" package. The variance among communities grouped by land use-location were tested using betadisper function in the same package followed by a permutation test for homogeneity of multivariate dispersions using the permutes function in the same package. When differences were found, pairwise differences between groups were checked using a Tuckey's HSD test using the TukeyHSD function.

\section{Results}

\subsection{Alpha Diversity: Diversity Incides}

The Table 1 shows the values of the richness, the Pielou's evenness index, the Shannon-Wiener diversity index and the Simpson diversity index of the plant communities blooming in spring, summer and autumn in the olive orchards, herbaceous and scrubland plots.

Table 1. Biodiversity indexes calculated the plant communities blooming by season and land used (Olive-olive orchards; Herb-herbaceous plots; Scrub-scrubland plots).

\begin{tabular}{ccccccccccc}
\hline & \multicolumn{3}{c}{ Spring } & \multicolumn{3}{c}{ Summer } & \multicolumn{3}{c}{ Autumn } \\
Biodiversity Indexes & Olive & Herb & Scrub & Olive & Herb & Scrub & Olive & Herb & Scrub \\
\hline Richness & 109 & 97 & 105 & 40 & 53 & 38 & 14 & 35 & 6 \\
Pielou & 0.749 & 0.644 & 0.664 & 0.593 & 0.642 & 0.718 & 0.605 & 0.624 & 0.150 \\
Shannon & 3.514 & 2.946 & 3.089 & 2.188 & 2.548 & 2.612 & 1.596 & 2.217 & 0.269 \\
Simpson & 0.957 & 0.917 & 0.915 & 0.790 & 0.879 & 0.879 & 0.666 & 0.830 & 0.109 \\
\hline
\end{tabular}

\subsection{Plants Communities in Spring, Summer and Autumn by Land Use and Location}

The Venn graphics showed that in all seasons several species were exclusive from each land use (Figure 1).

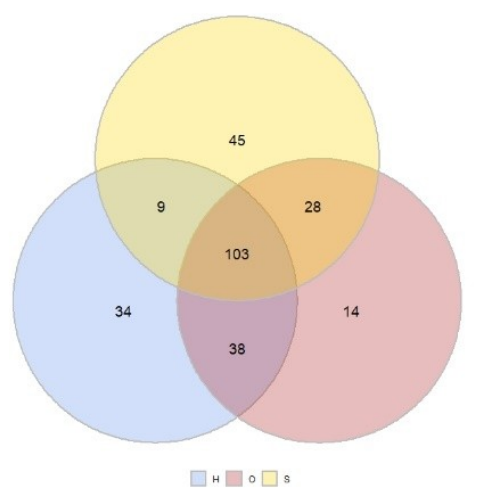

(a)

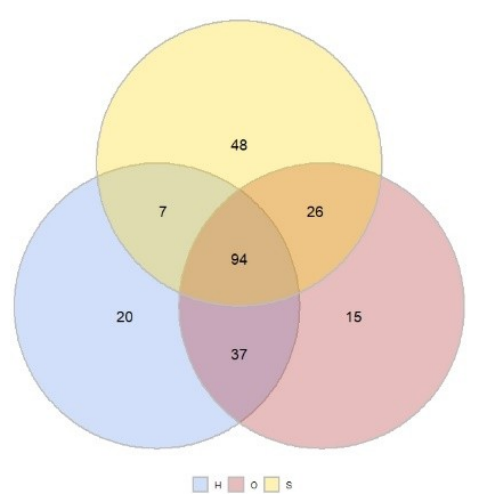

(b) 


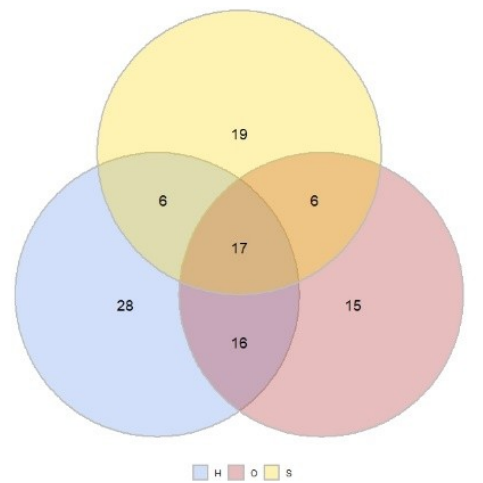

(c)

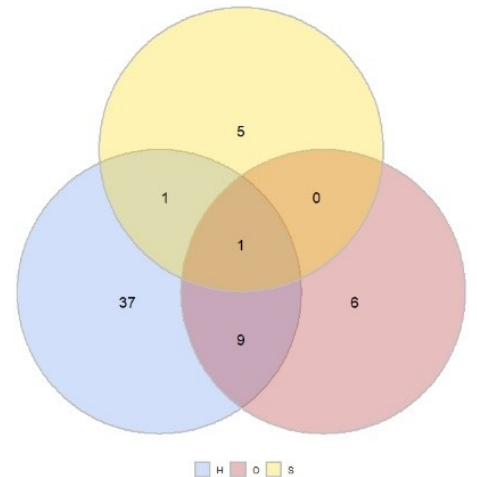

(d)

Figure 1. Venn graphics indicating the number of shared and non-shared species of the plant community blooming in the entire sampling period (a), spring (b), summer (c) and autumn (d). Hherbaceous plots, $\mathrm{O}-$ olive orchards, $\mathrm{S}-$ Scrubland plots.

The low number of shared species in summer and autumn did not allow to draw the NMDS plot for those seasons. The NMDS plot for visualizing the plant community blooming in spring by season and location is showed in the Figure 2.

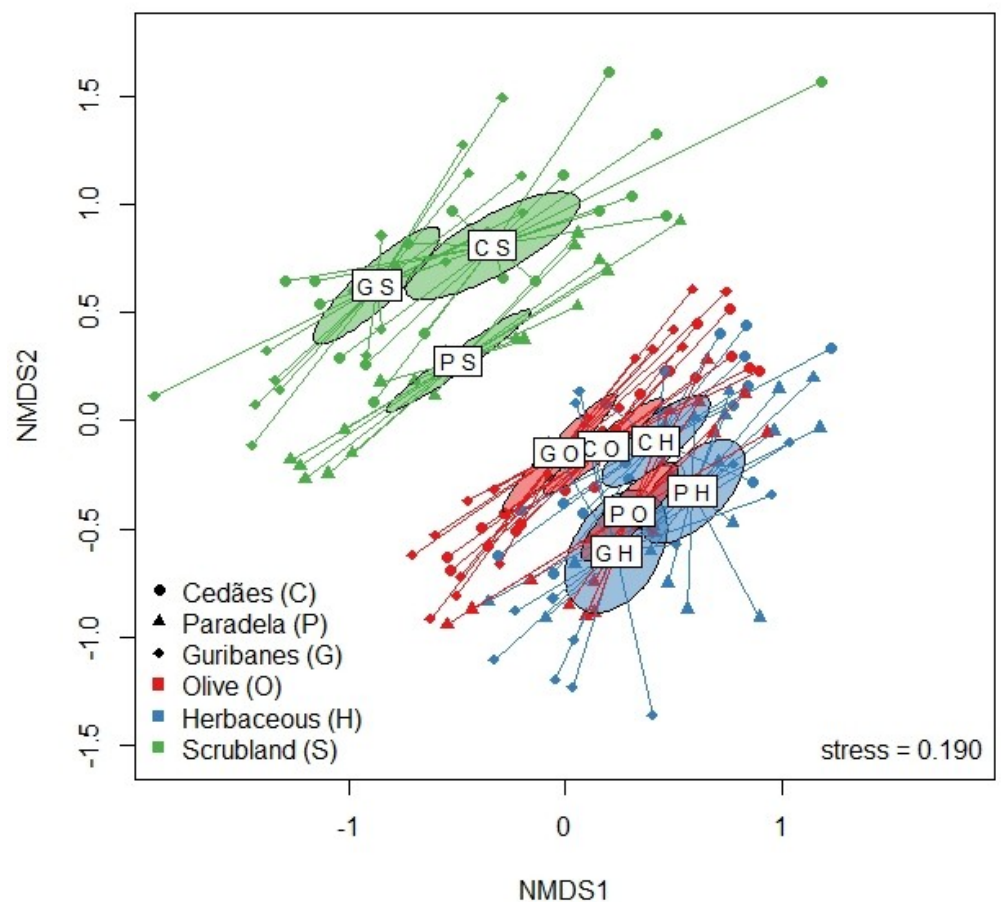

Figure 2. Non-metric multidimensional scaling (NMDS) analysis for flowering plant species (percentage of ground cover) in spring by the interaction of land use [olive $(\mathrm{O})$, herbaceous patches $(\mathrm{H})$, Scrubland (S)], and location [Cedães (C), Guribanes (G) and Paradela (P)]. Sites are connected to the centroid in each group, and the $95 \%$ confident interval of each centroid is shown by shaded ellipses.

The PERMANOVA in spring, summer and autumn showed that the plant communities varied with environment and location (Table 2). The Tuckey's HSD test indicated that: (i) in spring all plots presented different plant communities ( $p<0.05$ in all cases); (ii) in summer herbaceous plot in Cedães and the herbaceous plot in Paradela did not present differences in their community composition $(p=$ 
0.108 ) and all the other plots presented different community compositions ( $p<0.05$ in all cases), and (iii) in autumn did not find differences among the plant community in the scrubland from Cedães and any of the plots, among the plant community in the herbaceous plot from Cedães and the herbaceous plot in Paradela, the olive orchards of Cedães and Guribanes and the scrubland from Cedães and Guribanes, and among the herbaceous plot in Paradela and the olive orchards of Cedães and Guribanes and the scrubland in Cedães ( $p>0.108$ in all cases). The Tuckey's HSD test indicated that the communities among all the other plots in autumn differed ( $p<0.05$ in all cases).

Table 2. PERMANOVA results for the variations of the plant communities in spring, summer and autumn by location and land use.

\begin{tabular}{ccccccc}
\hline & & df & SS & $\mathbf{R}^{2}$ & Pseudo-F & $p$-Value \\
\hline Spring & Location & 2 & 12.525 & 0.044 & 20.479 & 0.001 \\
& Land use & 2 & 34.441 & 0.122 & 56.313 & 0.001 \\
& Location: Land use & 4 & 21.601 & 0.076 & 17.660 & 0.001 \\
& Residual & 702 & 214.672 & 0.758 & & \\
\hline Summer & Total & 710 & 283.239 & 1.000 & & \\
& Location & 2 & 13.188 & 0.072 & 22.556 & 0.001 \\
& Land use & 2 & 16.827 & 0.092 & 28.781 & 0.001 \\
& Location: Land use & 4 & 20.925 & 0.114 & 17.895 & 0.001 \\
& Residual & 452 & 132.134 & 0.722 & & \\
\hline \multirow{3}{*}{ Autumn } & Total & 460 & 183.074 & 1.000 & & \\
& Location & 2 & 9.045 & 0.136 & 17.299 & 0.001 \\
& Land use & 2 & 8.594 & 0.129 & 16.435 & 0.001 \\
& Location: Land use & 4 & 10.058 & 0.151 & 9.618 & 0.001 \\
& Residual & 149 & 38.955 & 0.584 & & \\
& Total & 157 & 66.651 & 1.000 & & \\
\hline
\end{tabular}

According to the permutation test for homogeneity, the variance of plant communities by land use and location in spring, summer and autumn were heterogeneous (spring: $\mathrm{F}=3.236, \mathrm{df}=8, p=$ 0.002; summer: $\mathrm{F}=2.357, \mathrm{df}=8, p=0.026$; autumn: $\mathrm{F}=3.626, \mathrm{df}=8, p=0.003$ ). The Tuckey HSD test showed that: (i) in spring the differences were due to the lower data dispersion around the centroid in the scrubland from Guribanes than in the herbaceous patches from Guribanes and Paradela (Figure A1a and A2a); (ii) in summer the differences were due to the higher data dispersion around the centroid in the scrubland from Guribanes than in the herbaceous patches of Guribanes $(p=0.033)$ and the olive orchard of Paradela $(p=0.009)$ (Figure A1b and A2b); (iii) and in autumn the Tuckey's HSD test found differences in the data dispersion of herbaceous plot in Guribanes with the olive orchard $(p=0.030)$ and herbaceous plot in Cedães $(p=0.011)$ and the scrubland plot in Paradela $(p=0.035)$ (Figures A1c and A2c). This was probably due to the fact that the herbaceous plot in Guribanes coped with most of the plant diversity in autumn. In the cases in which the variance of plant communities was different, the differences found by the PERMANOVA could be due to the heterogeneity of the data and not to a difference in the community composition.

\subsection{Simper Analysis: Species Divring the Differences among Land Uses and Sites and Most Abundant Species}

The simper analysis performed a total of 36 comparisons between plots in each season. Only the significant pairs in the Tuckey's HDS test after the permanova were analized. During spring a between 17 and 48 species (of a total of between 117 and 193 species) were responsible for the $70 \%$ of the differences among the community composition of flowering plants in the plots. The species that most contributed to the difference in each comparison was responsible for between $2 \%$ and $10 \%$ of the difference and coincided with the most abundant plants in the plots (Table 3). Also in some cases Coleostephus myconis (L.) Cass., Cistus ladanifer L. and Cytisus multiflorus (L'Her.) Sweet, were the species that most contributed to the difference among plots. During the summer between 5 and 10 
species (of a total of between 25 and 76 species) were responsible for the $70 \%$ of the differences differences among the community composition of flowering plants in the plots. The species that most contributed to the difference in each comparison was responsible for between $2.1 \%$ and $24.01 \%$ of the difference and, excepting Andryala integrifolia L., they coincided with the most abundant plants (Table 3). During the autumn between 2 and 11 species (of a total of 4 and 16 species, up to 50 in the comparisons with the herbaceous plot in Guribanes). were responsible for the $70 \%$ of the differences among the community composition of flowering plants in the plots. The species that most contributed to the difference in each comparison was responsible for between $2.53 \%$ and $67.03 \%$ of the difference and they coincided with the most abundant plants (Table 3). Also in some cases Foeniculum vulgare Mill. Was the species that most contributed to the difference among plots.

Table 3. Most abundant flowering species by season, site and land use.

\begin{tabular}{|c|c|c|c|c|}
\hline $\begin{array}{c}\text { Seaso } \\
\mathbf{n}\end{array}$ & Site & Olive Orchard & Herbaceous Plot & Scrubland Plot \\
\hline \multirow[t]{3}{*}{$\begin{array}{l}\text { Sprin } \\
\mathrm{g}\end{array}$} & Cedães & $\begin{array}{c}\text { Ornithopus } \\
\text { compressus L. }\end{array}$ & $\begin{array}{l}\text { Chamaemelum } \\
\text { mixtum (L.) All. }\end{array}$ & Lavandula pedunculata (Mill.) Cav. \\
\hline & $\begin{array}{c}\text { Guriba } \\
\text { nes }\end{array}$ & $\begin{array}{l}\text { Crepis capillaris } \\
\text { (L.) Wallr. }\end{array}$ & $\begin{array}{l}\text { Trifolium } \\
\text { michelianum Savi }\end{array}$ & L. pedunculata \\
\hline & $\begin{array}{l}\text { Parade } \\
\text { la }\end{array}$ & Bunias erucago L. & $\begin{array}{l}\text { Chrysanthemum } \\
\text { segetum L. }\end{array}$ & L. pedunculata \\
\hline \multirow[t]{3}{*}{$\begin{array}{l}\text { Sum } \\
\text { mer }\end{array}$} & Cedães & $\begin{array}{l}\text { Chondrilla juncea } \\
\text { L. }\end{array}$ & Chondrilla juncea L. & Helichrysum stoechas (L.) Moench \\
\hline & $\begin{array}{c}\text { Guriba } \\
\text { nes }\end{array}$ & $\begin{array}{l}\text { Chondrilla juncea } \\
\text { L. }\end{array}$ & $\begin{array}{l}\text { Hypochaeris radicata } \\
\text { L. }\end{array}$ & $\begin{array}{c}\text { Centaurea aristata subsp. langeana } \\
\text { (Arènes) Dostál }\end{array}$ \\
\hline & $\begin{array}{c}\text { Parade } \\
\text { la }\end{array}$ & $\begin{array}{c}\text { Andryala } \\
\text { integrifolia } \mathrm{L} .\end{array}$ & $\begin{array}{l}\text { Tolpis barbata (L.) } \\
\text { Gaertn. }\end{array}$ & Daphne gnidium L. \\
\hline \multirow[t]{3}{*}{$\begin{array}{c}\text { Autu } \\
\mathrm{mn}\end{array}$} & Cedães & $\begin{array}{l}\text { Chondrilla juncea } \\
\text { L. }\end{array}$ & Chondrilla juncea L. & Daphne gnidium L \\
\hline & $\begin{array}{c}\text { Guriba } \\
\text { nes }\end{array}$ & $\begin{array}{l}\text { Chondrilla juncea } \\
\text { L. }\end{array}$ & $\begin{array}{l}\text { Hypochaeris radicata } \\
\text { L. }\end{array}$ & Arbutus unedo L. \\
\hline & $\begin{array}{c}\text { Parade } \\
\text { la }\end{array}$ & $\begin{array}{l}\text { Chenopodium } \\
\text { album } \mathrm{L} .\end{array}$ & Chondrilla juncea L. & Daphne gnidium L \\
\hline
\end{tabular}

\section{Discussion}

In this study community composition of flowering plants in an important olive producer region from the north of Portugal was described. The results indicate that the community composition vary across the year. The spring was the most biodiverse season followed by the summer and the autumn. The community composition of flowering plants was generally different by land use (olive orchards, herbaceous vegetation and scrubland), in the three studied sites and in the three seasons, indicating a high variability of plants in the studied region. However, the species which most contributed to the difference in each pair of comparisons varied among one or two species for each land use and site and corresponded with the most abundant species. The high variability may be linked to the high landscape complexity of the studied region, composed mainly for small and irregular patches of several land uses, including many semi-natural areas with different composition (see [10].

The plants variability among seasons may contribute to a spillover of natural enemies among vegetation types and seasons. This type of spillover was described in olive orchards by [20] who identified movements of predators and parasitoids from ground cover to adjacent vegetation and to olive trees in different periods, in some cases corresponding to the development of important pests such as P. oleae. Additionally, Álvarez et al. [13] suggested that a spillover of natural enemies may occur between olive orchards and adjacent natural habitats when their resources differ in quality and quantity, as occurring in the present study. 
The variability in the plant composition among land uses may also contribute to pest reductions. For example, the anthophagous generation of $P$. oleae (spring) was reduced in some years with the increase of its specific parasitoid A. fuscicollis in orchards with ground covers [7], the landscape composition negatively affected $P$. oleae abundance [10] and the predation of $B$. oleae in olive orchards was associated to the area of scrublands in autumn [14]. However, it is important consider also the potential risks of flowering plants through potential benefits for pests [8] or vectors of diseases $[21,22]$.

\section{Conclusions}

In this study the community composition of flowering plants in an olive agroecosystem was described. The results indicate a high variability among land uses, sites and season, which include excusive flowering plant species and may potentially originate a spillover of arthropods. Further studies should study this potential spillover and effects on biological control.

Author Contributions: M.V. and J.P. conceived and designed the experiments; M.V. performed the experiments; M.V. and C.A. identified the plants; M.V. analyzed the data; M.V., S.S. and J.P. wrote the paper.

Acknowledgments: This work was supported by the Centro de Investigação de Montanha (CIMO) and M.V. Postdoc grant (SFRH/BPD/119487/2016)].

Conflicts of Interest: The authors declare no conflict of interest. The founding sponsors had no role in the design of the study; in the collection, analyses, or interpretation of data; in the writing of the manuscript, and in the decision to publish the results.

\section{Appendix A}

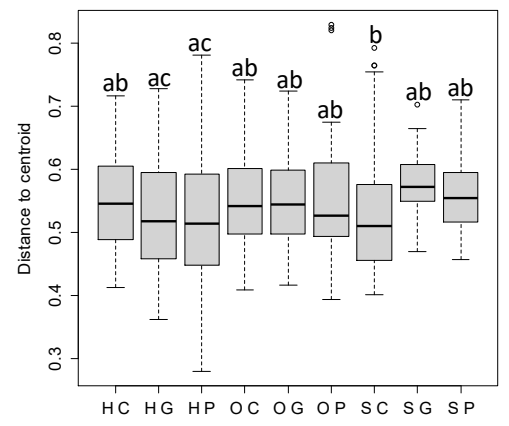

(a)

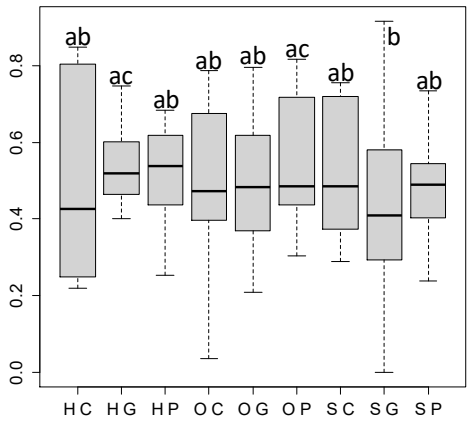

(b)

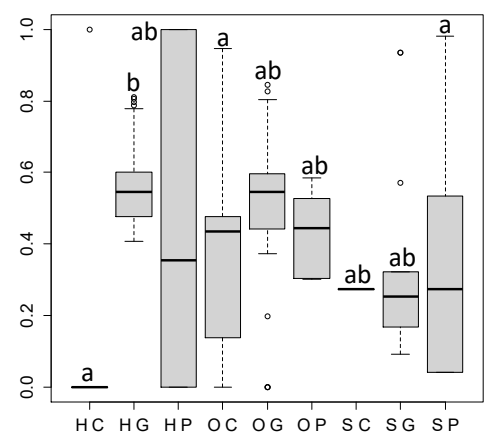

(b)

Figure A1. Variance of the plant communities in spring (a), summer (b) and autumn (c) by land use [olive $(\mathrm{O})$, herbaceous patches $(\mathrm{H})$, Scrubland $(\mathrm{S})$ ], and location [Cedães $(\mathrm{C})$, Guribanes $(\mathrm{G})$ and Paradela $(\mathrm{P})]$ as the distance to centroid of the Bray-Curtis distance matrix. Different letters indicate significant differences using a Tukey HSD test. Upper and lower hinges in the boxplot represent the first and third quartiles, error bar indicate $95 \%$ confidence intervals, and bar represents the median.

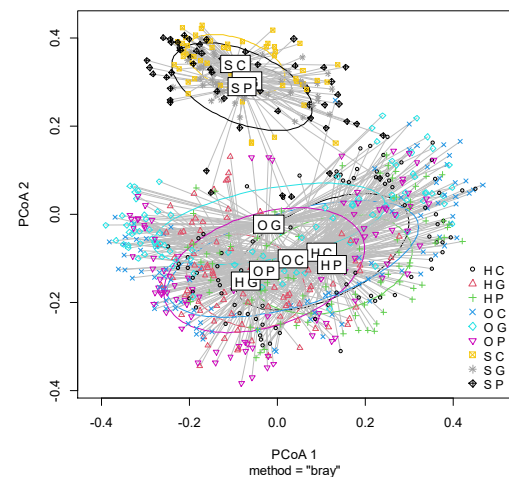

(a)

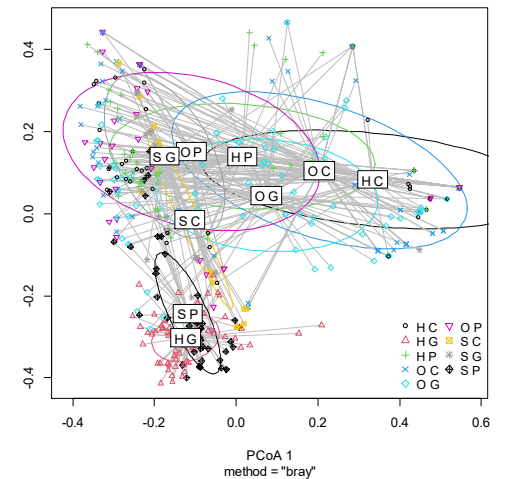

(b)

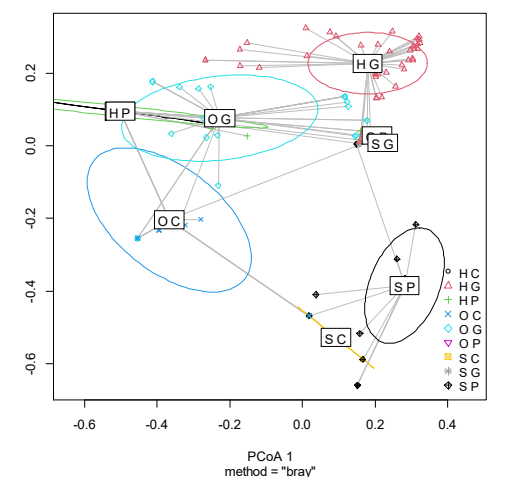

(b) 
Figure A2. Data points (points) and centroids (rectangles) across the two principal coordinates axes (PCoA1 and PCoA1) during spring (a), summer (b) and autumn (c). $\mathrm{H}-$ herbaceous patches, $\mathrm{O}-$ olive orchard, S-Scrubland, C-Cedães, G-Guribanes, P-Paradela.

\section{References}

1. Landis, D.L.; Wratten, S.D.; Gurr, G.M. Habitat management to conserve natural enemies of arthropod pests in agriculture. Annu. Rev. Entomol. 2000, 45, 175-201, doi:10.1146/annurev.ento.45.1.175.

2. Isaacs, R.; Tuell, J.; Fiedler, A.; Gardiner, M.; Landis, D. Maximizing arthropod-mediated ecosystem services in agricultural landscapes: The role of native plants. Front. Ecol. Environ. 2009, 7, 196-203, doi:10.1890/080035.

3. Wäckers, F., van Rijn, P.C.J. Pick and mix: Selecting flowering plants to meet the requirements of target biological control insects. In: Biodiversity and Insect Pests: Key Issues for Sustainable Management, 1st ed.; Gurr, G.M., Wratten, S.D., Snyder, W.E., Read, D.M.Y., Eds.; John Wiley \& Sons, Ltd.: Chichester, UK, 2012; pp. 139-165.

4. Alcalá Herrera, R.; Ruano, F.; Gálvez Ramírez, C.; Frischie, S.; Campos, M. Attraction of green lacewings (Neuroptera: Chrysopidae) to native plants used as ground cover in woody Mediterranean agroecosystems. Biol. Control 2019, 139, 104066, doi:10.1016/j.biocontrol.2019.104066.

5. Malheiro, R.; Casal, S.; Baptista, P.; Pereira, J.A. A review of Bactrocera oleae (Rossi) impact in olive products: From the tree to the table. Trends Food Sci. Technol. 2015, 44, 226-242, doi:10.1016/j.tifs.2015.04.009.

6. Villa, M.; Santos, S.A.P.; Marrão, R.; Pinheiro, L.A.; López-Saez, J.A.; Mexia, A.; Bento, A.; Pereira, J.A. Syrphids feed on multiple patches in heterogeneous agricultural landscapes during the autumn season, a period of food scarcity. Agric. Ecosyst. Environ. 2016, 233, 262-269, doi:10.1016/j.agee.2016.09.014.

7. Villa, M.; Santos, S.A.P.; Mexia, A.; Bento, A.; Pereira, J.A. Ground cover management affects parasitism of Prays oleae (Bernard). Biol. Control 2016, 96, 72-77, doi:10.1016/j.biocontrol.2016.01.012.

8. Villa, M.; Marrão, R.; Mexia, A.; Bento, A.; Pereira, J.A. Are wild flowers and insect honeydews potential food resources for adults of the olive moth, Prays oleae? J. Pest Sci. 2016, doi:10.1007/s10340-016-0745-8.

9. Villa, M.; Somavilla, I.; Santos, S.A.P.; López-Sáez, J.A.; Pereira, J.A. Pollen feeding habits of Chrysoperla carnea s.l. adults in the olive grove agroecosystem. Agric. Ecosyst. Environ. 2019, doi:10.1016/j.agee.2019.106573.

10. Villa, M.; Santos, S.A.P.; Sousa, J.P.; Ferreira, A.; Martins da Silva, P.; Patanita, I.; Ortega, M.; Pascual, S.; Pereira, J.A. Landscape composition and configuration affect the abundance of the olive moth (Prays oleae, Bernard) in olive grove". Agric. Ecosyst. Environ. 2020, 294, doi:10.1016/j.agee.2020.106854.

11. Paredes, D.; Cayuela, L.; Campos, M. Synergistic effects of ground cover and adjacent vegetation on natural enemies of olive insect pests. Agric. Ecosyst. Environ. 2013, 173, 72-80, doi:10.1016/j.agee.2013.04.016.

12. Gómez, J.A.; Campos, M.; Guzmán, G.; Castillo-Llanque, F., Vanwalleghem, T., Lora, A., Giráldez, J.V. Soil erosion control, plant diversity, and arthropod communities under heterogeneous cover crops in an olive orchard. Environ. Sci. Pollut. Res. 2018, 25, 977-989, doi:10.1007/s11356-016-8339-9.

13. Álvarez, H.A.; Morente, M.; Campos, M.; Ruano, F. La madurez de las cubiertas vegetales aumenta la presencia de enemigos naturales y la resiliencia de la red trófica de la copa del olivo. Ecosistemas 2019, 28, 92-106, doi:10.7818/ECOS.1779.

14. Ortega, M.; Sánchez-Ramos, I.; González-Núñez, M.; Pascual, S. Time course study of Bactrocera oleae (Diptera: Tephritidae) pupae predation in soil: The effect of landscape structure and soil condition. Agric. Forest Entomol. 2018, 20, 201-207, doi:10.1111/afe.12245.

15. Mueller-Dombois, D.: Ellenberg, H. Community Sampling: The Relevé Method. Aims and Methods of Vegetation Ecology; John Wiley and Sons: Hoboken, NJ, USA, 1974; pp. 45-66.

16. Oksanen, J.; Guillaume Blanchet, F.; Friendly, M.; Kindt, R.; Legendre, P.; McGlinn, D.; Minchin, P.R.; O'Hara, R.B.; Simpson, G.L.; Solymos, P.; et al. vegan: Community Ecology Package. R package Version 2.5-6. 2019. Available online: https://CRAN.R-project.org/package=vegan (accessed on 1 November 2020).

17. R Core Team. R: A Language and Environment for Statistical Computing; R Foundation for Statistical Computing: Vienna, Austria. 2020. Available online: https://www.R-project.org/ (accessed on 1 November 2020).

18. Hervé, M. RVAideMemoire: Testing and Plotting Procedures for Biostatistics. R package Version 0.9-78. 2020. Available online: https://CRAN.R-project.org/package=RVAideMemoire (accessed on 1 November 2020). 
19. Nelder, J.A. A reformulation of linear models. J. R. Stat. Soc. Ser. A Ger. 1977, 140, 48-77, doi:10.2307/2344517.

20. Álvarez, H.A.; Morente, M.; Shigeo, F.; Rodríguez, E., Campos, M.; Ruano, F. Semi-natural habitat complexity affects abundance and movement of natural enemies in organic olive orchards. Agric. Ecosyst. Environ. 2019, 285, 106618, doi:10.1016/j.agee.2019.106618.

21. Villa, M.; Rodrigues, I.; Baptista, P.; Fereres, A.; Pereira, J.A. Populations and host/non-host plants of spittlebugs nymphs in olive orchards from northeastern Portugal. Insects 2020, 11, 720; doi:10.3390/insects11100720.

22. Bodino, N.; Cavalieri, V.; Dongiovanni, C.; Saladini, M.A.; Simonetto, A.; Volani, S.; Plazio, E.; Altamura, G.; Tauru, D.; Gilioli, G.; et al. Spittlebugs of Mediterranean olive groves: Host-plant exploitation throughout the year. Insects 2020, 11, 130, doi:10.3390/insects11020130.

Publisher's Note: MDPI stays neutral with regard to jurisdictional claims in published maps and institutional affiliations.

(C) 2020 by the authors; licensee MDPI, Basel, Switzerland. This article is an open access article distributed under the terms and conditions of the Creative Commons by Attribution (CC-BY) license (http://creativecommons.org/licenses/by/4.0/). 